\title{
Effects of soybean isoflavone on intestinal antioxidant capacity and cytokines in young piglets fed oxidized fish oil
}

\author{
Lin $\mathrm{HUANG}^{\S}$, Xian-yong MA ${ }^{\S}$, Zong-yong JIANG ${ }^{\dagger+}$, You-jun HU, \\ Chun-tian ZHENG, Xue-fen YANG, Li WANG, Kai-guo GAO \\ (Institute of Animal Science, Guangdong Academy of Agricultural Sciences, the Key Laboratory of Animal Nutrition and Feed Science (South China) \\ of Ministry of Agriculture, State Key Laboratory of Livestock and Poultry Breeding, Guangdong Public Laboratory of Animal Breeding and Nutrition, \\ Guangdong Key Laboratory of Animal Breeding and Nutrition, Guangzhou 510640, China) \\ †E-mail: jiangz28@qq.com \\ Received Feb. 21, 2016; Revision accepted May 4, 2016; Crosschecked Nov. 10, 2016
}

\begin{abstract}
To investigate the effect of glycitein, a synthetic soybean isoflavone (ISF), on the intestinal antioxidant capacity, morphology, and cytokine content in young piglets fed oxidized fish oil, 72 4-d-old male piglets were assigned to three treatments. The control group was fed a basal diet containing fresh fish oil, and the other two groups received the same diet except for the substitution with the same dosage of oxidized fish oil alone or with ISF (oxidized fish oil plus ISF). After $21 \mathrm{~d}$ of feeding, supplementation of oxidized fish oil increased the levels of malondialdehyde (MDA), oxidized glutathione (GSSG), interleukin-1 $\beta$ (IL-1 $\beta$ ), tumor necrosis factor- $\alpha$ (TNF- $\alpha$ ), interleukin-2 (IL-2), nuclear factor $\mathrm{K} B(\mathrm{NF}-\mathrm{kB})$, inducible nitric oxide synthase (iNOS), NO, and Caspase-3 in jejunal mucosa, and decreased the villous height in duodenum and the levels of secretory immunoglobulin A (slgA) and IL-4 in the jejunal mucosa compared with supplementation with fresh oil. The addition of oxidized fish oil plus ISF partially alleviated this negative effect. The addition of oxidized fish oil plus ISF increased the villous height and levels of slgA and IL-4 in jejunal mucosa, but decreased the levels of IL-1 $\beta$ and IL-2 in jejunal mucosa $(P<0.05)$ compared with oxidized fish oil. Collectively, these results show that dietary supplementation of ISF could partly alleviate the negative effect of oxidized fish oil by improving the intestinal morphology as well as the antioxidant capacity and immune function in young piglets.
\end{abstract}

Key words: Young piglets, Oxidized fish oil, Growth performance, Soybean isoflavone, Antioxidant capacity http://dx.doi.org/10.1631/jzus.B1600078

CLC number: S828.5

\section{Introduction}

The intestine is an important organ in the defense against harmful endogenous and exogenous agents (Blikslager et al., 2007). However, many factors such

\footnotetext{
Corresponding author

$\S$ The two authors contributed equally to this work

* Project supported by the China Agriculture Research System (No. CARS-36), the Science and Technology Program of Guangdong Province (Nos. 2014A050503049 and 2013A061401020), the National Key Technology R \& D Program of China (No. 2012BAD39B01-5), and the Science and Technology Program of Guangzhou (No. 2014Y2-00121), China

(1D) ORCID: Xian-yong MA, http://orcid.org/0000-0002-5712-2573

(C) Zhejiang University and Springer-Verlag Berlin Heidelberg 2016
}

as pathogens, polyunsaturated fatty acids, and mildewed or oxidized feed can induce the oxidative stress (Slater, 1984; Halliwell and Chirico, 1993; Moreto and Perez-Bosque, 2009), especially in neonatal piglets (Chamulitrat et al., 1996; Aw, 1999; Lackeyram et al., 2012). These "stressors" induce intestinal injury and dysfunction by producing excessive reactive oxygen species (ROS) and destroy the antioxidant capacity in neonatal piglets (Moreto and Perez-Bosque, 2009; Maeda et al., 2010). Also, a series of pro-inflammatory cytokines such as tumor necrosis factor- $\alpha$ (TNF- $\alpha$ ) and interleukins- $1 \alpha,-1 \beta,-6$ (IL-1 $\alpha$, IL-1 $\beta$, IL-6) also are produced (Kelley, 2001). Oxidative stress involving ROS production is an 
important mediator of inflammation and immune activation (Aw, 1999; Ypsilantis et al., 2008), and ROS can cause injury to the intestinal mucosa (Mercer et al., 1996), but the mechanisms are not understood completely. The present study was designed to explore intestinal oxidative stress, provoked by including oxidized fish oil in the diet of young piglets, in an attempt to explain its influence on the development and immune function of the intestinal mucosa. Oxidative stress is lessened by the antioxidants (Otani et al., 2000; Kelley, 2001). Accumulating evidence suggests that supplementation of additives with antioxidant function (such as vitamin E, selenium, glutamine, and arginine) to the feed of piglets (Ban et al., 2004; Huang et al., 2011; Xi et al., 2011; Zhan et al., 2011) can reduce the oxidative stress and protect the intestinal function. Soybean isoflavones (ISFs) are stronger antioxidants, and have been studied extensively (Yousef et al., 2004; Foti et al., 2005; Lee et al., 2005; Jiang et al., 2007; Dixit et al., 2012). ISFs may inhibit the production and enhance the clearance of free radicals by inducing endogenous antioxidant enzymes such as superoxide dismutase (SOD), glutathione peroxidase (GSH-Px), catalase (CAT), etc. These results led us to speculate that dietary ISFs may reduce the intestinal oxidative stress in young piglets. The potential protective effects of ISFs on the intestinal oxidative stress in very young piglets have not been reported. The objective of the present study was to elucidate whether and how dietary ISFs affect the growth performance, intestinal antioxidant capacity, and intestinal function in young piglets fed oxidized fish oil.

\section{Materials and methods}

\subsection{Animals and diets}

Seventy-two 4-d-old male piglets Duroc $\times$ (Landrace $\times$ Yorkshire) were weighed $((1.80 \pm 0.04) \mathrm{kg})$ and randomly allotted to three treatments, each with six replicates of four animals. Each replicate of piglets was individually housed in $1.5 \mathrm{~m} \times 1.0 \mathrm{~m}$ pens with slatted stainless steel floors in a room held at $(32 \pm 1)^{\circ} \mathrm{C}$ with constant humidity. Piglets were fed a diet formulated to meet the requirements of NRC (2012) recommendation for 3-5 $\mathrm{kg}$ piglets (Table 1). The lipid source for the control group was $50 \mathrm{~g} / \mathrm{kg}$ fresh fish oil (Beihan Evergreen Aquatic Product Science \& Technology Co. Ltd., Guangdong, China), and the other two groups received the same diet except for the substitution with $50 \mathrm{~g} / \mathrm{kg}$ oxidized fish oil or $50 \mathrm{~g} / \mathrm{kg}$ oxidized fish oil plus $20 \mathrm{mg} / \mathrm{kg}$ ISF (prepared at the Institute of Animal Science, Guangdong Academy of Agricultural Sciences, containing 98.4\% glycitein). The fish oil was oxidized, as described by Andrew et al. (1960), and then stored at $-20^{\circ} \mathrm{C}$. The peroxide values were $186.89 \mathrm{mmol} / \mathrm{kg}$ for the oxidized fish oil and $4.20 \mathrm{mmol} / \mathrm{kg}$ for fresh fish oil. Details of ingredient composition and the calculated nutrient content of the diet are provided in Table 1. The diets were mixed with four weight equivalents of water just before each feeding and were provided without restriction every $3 \mathrm{~h}$ from 06:00 to 24:00. Piglets had free access to water. The animals quickly became accustomed to the feeding method and

Table 1 Ingredients and composition of the basal diet for young piglets (dry matter content)

\begin{tabular}{lc}
\hline \multicolumn{1}{c}{ Ingredient } & Composition (\%) \\
\hline Whole milk powder & 48.00 \\
Whey protein concentrate & 20.00 \\
Plasma protein powder & 5.00 \\
Fresh fish oil/oxidized fish oil & 5.00 \\
Whey & 6.89 \\
D,L-Methionine (98\%) & 0.30 \\
L-Tryptophan (98\%) & 0.02 \\
Liquid choline chloride (70\%) & 0.12 \\
Premix ${ }^{1,2,3}$ & 0.82 \\
Total & 100.00 \\
Chemical composition & \\
CP & 24.94 \\
ME (MJ/kg) & 18.16 \\
Crude fat & 15.16 \\
Lactose & 26.59 \\
Lys & 2.07 \\
Met + Cys & 1.20 \\
Thr & 1.20 \\
Trp & 1.20 \\
Ca & 1.02 \\
EP & 0.59 \\
\hline
\end{tabular}

${ }^{1}$ Premix was composed as follows (g/kg premix): piglet multivitamins $0.50 \mathrm{~g}$, minerals $2.00 \mathrm{~g}$, and emulsifying agent $1.00 \mathrm{~g}$. ${ }^{2}$ Vitamins contain: retinyl palmitate 6600 IU, cholecalciferol 660 IU, all-rac- $\alpha$-tocopheryl acetate $48 \mathrm{IU}$, menadione sodium bisulfite $1.50 \mathrm{mg}$, biotin $0.24 \mathrm{mg}$, folic acid $0.90 \mathrm{mg}$, nicotinic acid $60.0 \mathrm{mg}$, calcium pantothenate $36 \mathrm{mg}$, riboflavin $12.0 \mathrm{mg}$, thiamin $4.5 \mathrm{mg}$, pyridoxine $6.0 \mathrm{mg}$, cyanocobalamin $60.0 \mu \mathrm{g} .{ }^{3}$ Minerals contain: ferric $105 \mathrm{mg}$, copper $10 \mathrm{mg}$, manganese $5 \mathrm{mg}$, zinc $110 \mathrm{mg}$. CP: crude protein; ME: metabolizable energy; EP: essential fat 
consumed each meal without spillage. Feed intake (on an as-fed basis) per pen was calculated based on $25 \%$ of the weight difference of the feed before and after each feeding (dry weight/liquid weight=1:4). The body weights (BWs) of all piglets were measured on the 1st day and the 21st day of the experiment. Average daily gain (ADG), average daily feed intake (ADFI, dry weight), and gain/feed (G:F) ratios were calculated.

\subsection{Sample collection}

Two randomly chosen piglets from each pen were fasted for $12 \mathrm{~h}$ and then sacrificed after weighing on the 21st day of experiment by muscular injection of sodium pentobarbital ( $40 \mathrm{mg} / \mathrm{kg}$ of BW). The small intestine, immediately ligated from the pyloric sphincter to the ileocolonic junction, was rapidly removed along the mesenteric border on an ice-cold metal plate. The segment of small intestine proximal to the ligament of Treitz was designated as the duodenum; the remainder was divided into two equal lengths, jejunum proximal and ileum distal, as described by Burrin et al. (2000). A $5-\mathrm{cm}$ piece from the middle of the jejunum was opened longitudinally and gently but thoroughly cleaned with ice-cold phosphate buffered saline (PBS) containing $137 \mathrm{mmol} / \mathrm{L}$ $\mathrm{NaCl}, 2.7 \mathrm{mmol} / \mathrm{L} \mathrm{KCl}, 10 \mathrm{mmol} / \mathrm{L} \mathrm{Na}_{2} \mathrm{HPO}_{4}$, and $2 \mathrm{mmol} / \mathrm{L} \mathrm{KH}_{2} \mathrm{PO}_{4}$, $\mathrm{pH}$ 7.4. Jejunal mucosa was collected by scraping with a glass slide, and a portion was snap-frozen in liquid nitrogen.

\subsection{Small intestinal morphology}

Additional samples were collected from consistent locations (the duodenal sampling site was located $2 \mathrm{~cm}$ from the opening of the pancreatic duct, and the ileum sampling site was located $2 \mathrm{~cm}$ from the cecum) of each segment of the intestine, rinsed as above, and then fixed in $10 \%$ neutral buffered formalin overnight or longer. Paraffin-embedded sections were prepared from each sample in duplicate, stained with hematoxylin and eosin, and used for histometric measurements, as described by Jensen et al. (2001). The mean villous height, crypt depth, and intestinal circumference were measured using an Axiophot microscope (Philips, Holland) and National Institutes of Health (NIH) image software version 1.60 (Bethesda, MD, USA) in at least 20 vertically well-oriented villus-crypt columns. The villous area was calculated as described by Frankel et al. (1993).

\subsection{Analyses of antioxidant enzymes and cytokines}

The frozen jejunal mucosa was homogenized in PBS ( $9 \mathrm{ml}$ added per gram tissue) at $4{ }^{\circ} \mathrm{C}$ using an Ultra-Turrax T8 homogenizer (IKA Labortechnik, Staufen, Germany) for 1-2 min at 3000-5000 r/min. The homogenates were centrifuged $(4000 \mathrm{~g}$ for $5 \mathrm{~min}$ at $4{ }^{\circ} \mathrm{C}$ ) and the supernatants were used for determining the indices of antioxidant capacity and concentrations of cytokines. The antioxidant indicators, namely GSH-Px, SOD, CAT, GSH, oxidized glutathione (GSSG), and malondialdehyde (MDA), were quantified using assay kits (Nanjing Jiancheng Bioengineering Institute, China), previously validated in house for porcine tissue. Secretory immunoglobulin A (sIgA), IL-1 $\beta$, IL-2, IL-4, IL-10, interferon- $\gamma($ IFN- $\gamma$ ), TNF- $\alpha$, inducible nitric oxide synthase (iNOS), and nuclear factor $\kappa \mathrm{B}(\mathrm{NF}-\kappa \mathrm{B})$ were measured using porcine enzyme-linked immunosorbent assay (ELISA) kits (Groundwork Biotechnology Diagnosticate, San Diego, CA, USA) through an automated ELISA reader (Model 550, Bio-Rad, Hercules, CA, USA).

\subsection{Statistical analysis}

All data were analyzed using replicates as the experimental unit $(n=6)$. The effect of treatment on each variable was analyzed by one-way analysis of variance (ANOVA) using the GLM procedure of SAS (Version 8.2, SAS Institute, Cary, NC, USA). $P \leq 0.05$ was considered to be statistically different.

\section{Results}

\subsection{Growth performance}

The effects of feeding ISF and oxidized fish oil for $21 \mathrm{~d}$ on growth performance of young piglets are shown in Table 2. The final BW, ADG, or G:F ratio of piglets fed oxidized fish oil was significantly lower than that of piglets in control group $(P<0.05)$, while the final $\mathrm{BW}, \mathrm{ADG}$, or $\mathrm{G}: \mathrm{F}$ ratio of piglets fed oxidized fish oil plus ISF has a trend to increase compared with those piglets fed oxidized fish oil. There was no difference in ADFI among treatments $(P>0.05)$.

\subsection{Small intestinal morphology}

The piglets fed oxidized fish oil had significantly lower villous height in the duodenum, jejunum, and 
ileum than the piglets fed fresh fish oil and those fed oxidized fish oil plus ISF $(P<0.05$; Table 3$)$. Crypt depth, villous height/crypt depth, and villous area in the jejunum were not significantly different among the three treatments $(P>0.05)$.

\subsection{Antioxidant capacity in jejunal mucosa}

The effects of ISF and oxidized fish oil for $21 \mathrm{~d}$ of feeding on the antioxidant capacity in the jejunal mucosa of neonatal piglets are shown in Table 4 . The levels of MDA and GSSG in piglets fed fresh fish oil diet and oxidized fish oil plus ISF diets were all significantly lower than those in piglets fed oxidized fish oil diet alone $(P<0.05)$. The ratio of GSH to GSSG was higher in piglets fed fresh fish oil diets than in those fed oxidized fish oil alone or oxidized fish oil plus ISF $(P<0.05)$. The activity of GSH-Px in piglets fed oxidized fish oil plus ISF was significantly higher than that in piglets fed oxidized fish oil along or fresh fish oil along. There were no differences in SOD, CAT, or GSH among three treatments $(P>0.05)$.

Table 2 Effects of dietary soybean isoflavone addition on growth performance of young piglets fed a diet with oxidized fish oil

\begin{tabular}{lccccc}
\hline Treatment $^{1}$ & Initial BW $(\mathrm{kg})$ & Final BW $(\mathrm{kg})^{\mathrm{a}}$ & ADG $(\mathrm{g} / \mathrm{d})$ & ADFI $(\mathrm{g} / \mathrm{d})$ & $\mathrm{G} / \mathrm{F}(\mathrm{g} / \mathrm{g})$ \\
\hline FFO & 1.77 & $7.58^{\mathrm{a}}$ & $290.00^{\mathrm{a}}$ & 240.00 & $1.20^{\mathrm{a}}$ \\
OFO & 1.78 & $6.70^{\mathrm{b}}$ & $255.00^{\mathrm{b}}$ & 239.00 & $1.06^{\mathrm{b}}$ \\
OFO+20 ISF & 1.79 & $7.15^{\mathrm{ab}}$ & $268.00^{\mathrm{ab}}$ & 240.00 & $1.11^{\mathrm{ab}}$ \\
\hline SEM & 0.04 & 0.18 & 7.73 & 4.95 & 0.03 \\
$P$-value & 0.947 & 0.047 & 0.019 & 0.955 & 0.038 \\
\hline
\end{tabular}

${ }^{\mathrm{a}, \mathrm{b}}$ Means $(n=6)$ in a column with different superscripts are significantly different $(P<0.05) .{ }^{1}$ Diets are designated as FFO for fresh fish oil diet or OFO for oxidized fish oil diet; 20 ISF is supplemented with $20 \mathrm{mg} / \mathrm{kg}$ soybean isoflavone. BW: body weight; ADG: average daily gain; ADFI: average daily feed intake; G/F: gain/feed; SEM: standard error of the mean

Table 3 Effect of dietary soybean isoflavone addition on morphology of intestine in young piglets fed a diet with oxidized fish oil

\begin{tabular}{|c|c|c|c|c|c|c|}
\hline \multirow{2}{*}{ Treatment $^{1}$} & \multicolumn{3}{|c|}{ Villous height $(\mu \mathrm{m})$} & \multicolumn{3}{|c|}{ Crypt depth $(\mu \mathrm{m})$} \\
\hline & Duodenum & Jejunum & Ileum & Duodenum & Jejunum & Ileum \\
\hline FFO & $502.00^{\mathrm{a}}$ & $536.00^{\mathrm{a}}$ & $495.00^{\mathrm{a}}$ & 169.00 & 144.00 & 148.00 \\
\hline OFO & $439.00^{\mathrm{b}}$ & $465.00^{\mathrm{b}}$ & $478.00^{\mathrm{b}}$ & 150.00 & 183.00 & 177.00 \\
\hline $\mathrm{OFO}+20 \mathrm{ISF}$ & $539.00^{\mathrm{a}}$ & $503.00^{\mathrm{a}}$ & $498.00^{\mathrm{a}}$ & 199.00 & 153.00 & 139.00 \\
\hline SEM & 18.74 & 20.61 & 22.14 & 15.46 & 18.65 & 16.72 \\
\hline$P$-value & 0.009 & 0.047 & 0.050 & 0.116 & 0.313 & 0.280 \\
\hline \multirow{2}{*}{ Treatment $^{1}$} & \multicolumn{3}{|c|}{ Villous height:crypt depth } & \multicolumn{3}{|c|}{ Villous area $\left(\times 10^{5} \mu \mathrm{m}^{2}\right)$} \\
\hline & Duodenum & Jejunum & Ileum & Duodenum & Jejunum & Ileum \\
\hline FFO & 3.09 & 3.65 & 2.83 & 3.48 & 3.71 & 3.18 \\
\hline OFO & 3.00 & 3.00 & 3.30 & 3.20 & 3.13 & 2.58 \\
\hline $\mathrm{OFO}+20 \mathrm{ISF}$ & 2.56 & 3.31 & 3.45 & 4.14 & 3.70 & 3.40 \\
\hline SEM & 0.19 & 0.31 & 0.30 & 0.36 & 0.24 & 0.41 \\
\hline$P$-value & 0.196 & 0.347 & 0.431 & 0.201 & 0.171 & 0.471 \\
\hline
\end{tabular}

${ }^{\mathrm{a}, \mathrm{b}}$ Means $(n=6)$ in a column with different superscripts are significantly different $(P<0.05) .{ }^{1}$ Diets are designated as FFO for fresh fish oil diet or OFO for oxidized fish oil diet; 20 ISF is supplemented with $20 \mathrm{mg} / \mathrm{kg}$ soybean isoflavone; SEM: standard error of the mean

Table 4 Effect of dietary soybean isoflavone addition on antioxidant indices of jejunal mucosa in young piglets fed a diet with oxidized fish oil

\begin{tabular}{lccccccc}
\hline Treatment $^{1}$ & $\begin{array}{c}\text { MDA } \\
(\mathrm{mmol} / \mathrm{ml})\end{array}$ & $\begin{array}{c}\text { SOD } \\
(\mathrm{U} / \mathrm{g} \text { prot })\end{array}$ & $\begin{array}{c}\text { GSH-Px } \\
(\mathrm{U} / \mathrm{g} \text { prot})\end{array}$ & $\begin{array}{c}\text { CAT } \\
(\mathrm{U} / \mathrm{g} \text { prot })\end{array}$ & $\begin{array}{c}\text { GSH } \\
(\mathrm{mmol} / \mathrm{mg} \text { prot})\end{array}$ & $\begin{array}{c}\text { GSSG } \\
(\mathrm{mmol} / \mathrm{mg} \text { prot})\end{array}$ & GSH/GSSG \\
\hline FFO & $3.17^{\mathrm{b}}$ & 9.14 & $53.33^{\mathrm{b}}$ & 1.32 & 10.88 & $8.58^{\mathrm{b}}$ & $1.35^{\mathrm{a}}$ \\
OFO & $5.20^{\mathrm{a}}$ & 7.21 & $59.84^{\mathrm{b}}$ & 1.23 & 9.08 & $12.62^{\mathrm{a}}$ & $0.77^{\mathrm{b}}$ \\
OFO+20 ISF & $2.40^{\mathrm{c}}$ & 8.33 & $91.46^{\mathrm{a}}$ & 1.80 & 8.33 & $9.56^{\mathrm{b}}$ & $0.89^{\mathrm{b}}$ \\
\hline SEM & 0.03 & 0.68 & 7.29 & 0.17 & 1.01 & 1.09 & 0.15 \\
$P$-value & $<0.001$ & 0.147 & 0.005 & 0.073 & 0.219 & 0.048 & 0.031 \\
\hline
\end{tabular}

${ }_{\mathrm{a}, \mathrm{b}, \mathrm{c}}$ Means $(n=6)$ in a column with different superscripts are significantly different $(P<0.05) .{ }^{1}$ Diets are designated as FFO for fresh fish oil diet or OFO for oxidized fish oil diet; $20 \mathrm{ISF}$ is supplemented with $20 \mathrm{mg} / \mathrm{kg}$ soybean isoflavone. MDA: maleic dialdehyde; SOD: superoxide dismutase; GSH-Px: glutathione peroxidase; CAT: catalase; GSH: glutathione; GSSG: oxidized glutathione; prot: protein; SEM: standard error of the mean 


\subsection{Cell-mediated immunologic factors}

Piglets fed oxidized fish oil diet had lower concentrations of $\operatorname{sg} \mathrm{A}$ and higher IL- $1 \beta$ and IL-2 in jejunal mucosa than piglets fed fresh fish oil and those fed oxidized fish oil plus ISF $(P \leq 0.05$; Table 5). Piglets fed oxidized fish oil diet had higher concentrations of TNF- $\alpha$ in jejunal mucosa than piglets fed fresh fish oil $(P<0.05)$, whereas its concentrations were numerically lower in piglets fed oxidized fish oil plus ISF diet, but did not differ from those fed fresh fish oil. All piglets fed oxidized fish oil diets had significantly lower IL-4 concentrations than those fed fresh fish oil, but no significant differences from the groups supplemented with oxidized fish oil and oxidized fish oil plus ISF. There were no significant differences in jejunal concentrations of IL-6, IL-8, IL-10, or IFN- $\gamma$ among the three treatments.

\subsection{Jejunal mucosal NF-kB, iNOS, NO, and Caspase-3}

Piglets fed oxidized fish oil diet had higher jejunal concentrations of NF- $\mathrm{kB}$, iNOS and Caspase-3, and lower NO than piglets fed fresh fish oil $(P \leq 0.05$; Table 6), and supplemental ISF decreased the concentrations of NF- $\mathrm{kB}$ in jejunal mucosa and partially offset these differences on the concentrations of iNOS, Caspase- 3 and NO between the two groups fed fresh fish oil and oxidized fish oil.

\section{Discussion}

This is the first study to demonstrate that dietary ISF could partly alleviate the oxidative stress induced by oxidized fish oil by improving the intestinal morphology, antioxidant capacity, and immune function in young piglets. Our findings support the potential of ISF as an intestinal protective agent in young piglets with its attenuation of intestinal damage induced by oxidative stress. Although several studies have evaluated the effectiveness of ISF on piglets (de Wilde et al., 2004; Mau et al., 2008; Goerke et al., 2012), none of these studies examined the effectiveness of ISF treatment on the oxidative stress and immune function of the piglets.

Numerous studies have shown that feeding oxidized fish oil to experimental animals can result in excessive production of ROS and MDA, the reduction of SOD, and the induction of oxidative stress (John et al., 1959; Liu and Lee, 1998; Aw, 1999; VázquezAñón and Jenkins, 2007). In the present

Table 5 Effect of dietary soybean isoflavone addition on the cell-mediated immunologic factors of jejunal mucosa ${ }^{1}$ in young piglets fed a diet with oxidized fish oil

\begin{tabular}{|c|c|c|c|c|c|c|c|c|c|}
\hline Treatment $^{2}$ & $\begin{array}{c}\text { sIgA } \\
(\mu \mathrm{g} / \mathrm{ml})\end{array}$ & $\begin{array}{c}\mathrm{IL}-1 \beta \\
(\mathrm{pg} / \mathrm{ml})\end{array}$ & $\begin{array}{l}\text { TNF- } \alpha \\
(\mathrm{pg} / \mathrm{ml})\end{array}$ & $\begin{array}{c}\text { IL-2 } \\
(\mathrm{pg} / \mathrm{ml})\end{array}$ & $\begin{array}{c}\text { IL-4 } \\
(\mathrm{ng} / \mathrm{ml})\end{array}$ & $\begin{array}{c}\text { IL-6 } \\
(\mathrm{pg} / \mathrm{ml})\end{array}$ & $\begin{array}{c}\text { IL-8 } \\
(\mathrm{pg} / \mathrm{ml})\end{array}$ & $\begin{array}{c}\text { IL-10 } \\
(\mathrm{ng} / \mathrm{ml})\end{array}$ & $\begin{array}{c}\text { IFN- } \gamma \\
(\mathrm{ng} / \mathrm{ml})\end{array}$ \\
\hline FFO & $81.59^{\mathrm{a}}$ & $108.90^{b}$ & $30.55^{b}$ & $112.86^{b}$ & $50.67^{\mathrm{a}}$ & 27.69 & 134.84 & 4.63 & 6.22 \\
\hline $\mathrm{OFO}+20 \mathrm{ISF}$ & $78.90^{\mathrm{a}}$ & $111.23^{b}$ & $42.68^{\mathrm{ab}}$ & $108.25^{b}$ & $35.88^{b}$ & 30.81 & 106.13 & 4.92 & 7.96 \\
\hline SEM & 9.41 & 9.55 & 9.55 & 7.09 & 3.76 & 4.23 & 11.60 & 0.71 & 0.81 \\
\hline
\end{tabular}

${ }_{\mathrm{a}, \mathrm{b}, \mathrm{c}}$ Means $(n=6)$ in a column with different superscripts are significantly different $(P \leq 0.05) .{ }^{1}$ Data are mean concentrations in supernatants of $1: 10$ homogenates. ${ }^{2}$ Diets are designated as FFO for fresh fish oil diet or OFO for oxidized fish oil diet; 20 ISF is supplemented with $20 \mathrm{mg} / \mathrm{kg}$ soybean isoflavone. sIgA: secretory immunoglobulin A; IL: interleukin; TNF- $\alpha$ : tumor necrosis factor $\alpha$; IFN- $\gamma$ : interferon $\gamma$; SEM: standard error of the mean

Table 6 Effect of dietary soybean isoflavone addition on the co-oxidation and immune-related factors of jejunal mucosa ${ }^{1}$ in young piglets fed a diet with oxidized fish oil

\begin{tabular}{lcccc}
\hline Treatment $^{2}$ & $\mathrm{NO}(\mu \mathrm{g} / \mathrm{ml})$ & NF- $\kappa \mathrm{B}(\mathrm{pg} / \mathrm{ml})$ & iNOS $(\mathrm{ng} / \mathrm{ml})$ & Caspase-3 $(\mu \mathrm{g} / \mathrm{ml})$ \\
\hline FFO & $8.67^{\mathrm{a}}$ & $66.06^{\mathrm{b}}$ & $12.11^{\mathrm{b}}$ & $67.77^{\mathrm{b}}$ \\
OFO & $5.51^{\mathrm{b}}$ & $81.93^{\mathrm{a}}$ & $17.09^{\mathrm{a}}$ & $81.04^{\mathrm{a}}$ \\
OFO+20 ISF & $6.77^{\mathrm{ab}}$ & $73.61^{\mathrm{b}}$ & $16.03^{\mathrm{a}}$ & $72.34^{\mathrm{ab}}$ \\
\hline SEM & 0.80 & 6.73 & 1.10 & 7.05 \\
$P$-value & 0.054 & 0.052 & 0.019 & 0.055 \\
\hline
\end{tabular}

${ }^{\mathrm{a}, \mathrm{b}}$ Means $(n=6)$ in a row with different superscripts are significantly different $(P \leq 0.05) .{ }^{1}$ Data are mean concentrations in supernatants of $1: 10$ homogenates. ${ }^{2}$ Diets are designated as FFO for fresh fish oil diet or OFO for oxidized fish oil diet; 20 ISF is supplemented with $20 \mathrm{mg} / \mathrm{kg}$ soybean isoflavone. NO: nitric oxide; NF- $\kappa \mathrm{B}$ : nuclear factor $\kappa \mathrm{B}$; iNOS: inducible nitric oxide synthase; SEM: standard error of the mean 
study, the content of MDA in the jejunal mucosa of piglets fed oxidized fish oil was significantly higher, and the activity of GSH-Px and ratio of GSH/GSSG were lower than those of piglets fed diets containing fresh fish oil. The lower intestinal morphometry, especially the reduction in duodenal villous height, is consistent with oxidative damage to the intestine, thus providing a potentially valuable model of the influence of oxidative stress on intestinal development and the associated function.

Previous studies have indicated that ISF improved the antioxidant activity in the breast muscle of male broilers fed oxidized fish oil (Jiang et al., 2007). Liu et al. (2005) also used soy ISF extracts to elevate the activities of many antioxidant enzymes in rats fed diets containing partially oxidized oil and proved that ISF alleviated the negative effect of oxidized fish oil. Our present results show that the balance of antioxidant/oxidant status in the intestine of piglets is disturbed by feeding oxidized fish oil and partially reverted by feeding ISF. The concentrations of MDA and GSSG in piglets fed oxidized fish oil increased, while they were decreased by the inclusion of ISF in the diet. The activity of GSH-Px changed in the opposite direction. These findings indicate that intestinal oxidative stress provoked by feeding oxidized fish oil is reduced by ISF.

Our present results show that the final BW and ADG are significantly lower in piglets fed oxidized fish oil diet, but the addition of ISF restores BW and ADG to the levels of the control group fed fresh fish oil. Note that the high values of the G:F ratio result from the feed being of very high dry matter (DM) content compared to the much lower expected DM content of these young pigs. As reported earlier with broilers (Jiang et al., 2007) and piglets (Yuan, 2007), the addition of ISF offsets the deleterious effect of oxidized fish oil on growth performance.

Growth retardation of weaned piglets was related to the reduction of villous height (Cera et al., 1988). Yuan (2007) found that oxidative stress caused by feeding oxidized fish oil decreased the villous dimensions in piglets and their growth. The present study demonstrates that the addition of oxidized fish oil to piglets decreases the duodenal villous height, and $20 \mathrm{mg} / \mathrm{kg}$ ISF protects the duodenal villi from the deleterious effects of oxidized fish oil. Presumably, ISF, by stimulating antioxidant function, confers some degree of protection on the intestinal mucosa, helping to improve the growth performance.

It has been reported that atrophic changes in the intestinal mucosa, like those caused here by oxidized fish oil, provoke immediate or delayed-type hypersensitivity and mucosal inflammation (Li et al., 1990; 1991). Our results show that $\operatorname{sg} A$ is decreased by feeding oxidized fish oil, whereas supplemental ISF markedly increases the intestinal IgA levels, probably by augmenting B- and T-cell counts (Fan et al., 2010). The IgA-mediated intestinal immune response is controlled by the balance between opposing actions of the Th2-type IgA-stimulating and the Th1-type IgA-inhibiting cytokines from their respective lymphocyte subsets (Kudsk, 2001; Pruett, 2003; Shang et al., 2004). Th1-mediated cytokines such as IL-1 $\beta$, IL-2, and TNF- $\alpha$ enhance cell-mediated immunity, and are produced by Th1 lymphocytes. A predominant Th1 effect results in the activation of $\mathrm{T}$ lymphocytes. Th2 cytokines such as IL-4 and IL-10 enhance humoral immunity, and are produced by Th2 lymphocytes (Kalinski and Moser, 2005). A predominant effect of Th2 lymphocytes results in the activation of B lymphocytes and upregulation of antibody production. There was a shift from $\mathrm{Th} 1$ to Th2 profiles of cytokines in the jejunal extracts from the ISF-fed piglets, as the levels of IL-4 declined significantly and those of IL-1 $\beta$, IL-2, and TNF- $\alpha$ increased, compared to piglets fed oxidized fish oil alone. The pattern of changes in IL-4 levels closely approximated those of IgA (Fan et al., 2010). Deng et al. (2010) reported that diets supplemented with antioxidants decreased the serum levels of inflammatory cytokines in post-weaning piglets. Morimoto et al. (2009) found less inflammation and colonic tissue damage in mice supplemented with ISF than in control mice with experimental colitis, and Kim et al. (2004) found that ISF inhibited IL-1-induced upregulation of NF- $\mathrm{KB}$ activation.

Pathogens that cause acute inflammation activate the NF- $\mathrm{kB}$ and iNOS pathways, thereby regulating genes encoding pro-inflammatory cytokines, chemokines, and adhesion molecules (Jelínková et al., 2004). Gookin et al. (2002) demonstrated that the villous epithelium is the predominant site of iNOS expression and that the lack of iNOS in porcine decreases the inflammatory responses (Pampusch et al., 1998). Epithelial iNOS expression has likewise been reported 
in mice experimentally infected with Cryptosporidium parvum (Leitch and He, 1999). Other reports also showed that the epithelium is capable of rapid synthesis of iNOS after acute gut injury (Banan et al., 2001; Gookin et al., 2002). The novelty of the present study is that the concentrations of iNOS and Caspase-3 were increased by oxidized fish oil but the increase was partially alleviated by supplementation of ISF. Caspase- 3 also is activated by oxidative stress and helps to increase the inflammatory response (Ozacmak et al., 2014), which is consistent with our result. In addition, the concentration of NF- $\mathrm{KB}$ in this present study increased significantly in the young piglets fed oxidized fish oil diets, consistent with the hypothesis that oxidative stress in the intestinal mucosa increases ROS and then increases expression of proinflammatory cytokines via activating NF- $\mathrm{kB}$ (Aw, 1999). NF- $\mathrm{KB}$ was partially reduced in the piglets fed oxidized fish oil plus ISF compared to that in the piglets fed oxidized fish oil alone, a finding consistent with that from other models (Valachovicova et al., 2004; Li et al., 2005). The most striking benefit was the reduction in NF- $\mathrm{kB}$ seen in piglets fed oxidized fish oil plus ISF diets. It appears that NO modulates the phenotype of T-helper cells to promote a shift from Th1 to Th2, accompanied by a decline in pro-inflammatory mediators including IL-2 and by an increase in anti-inflammatory mediators such as IL-4 (Chang et al., 1997; Taylor-Robinson, 1997; Daniel et al., 2006). NO decreased in the jejunal mucosa of piglets fed oxidized fish oil alone, while the decrease was less in the piglets fed oxidized fish oil plus ISF. NO is also involved in activation of Caspase-3 (Parikh et al., 2003), and in this present research NO was decreased in piglets fed oxidized fish oil; probably, the activation of Caspase- 3 needs the consumption of NO.

The antioxidant properties of ISF are both direct, by scavenging or quenching oxygen free radicals thereby inhibiting MDA production, and indirect, by preventing increased membrane permeability resulting from oxidative stress, in many tissues including liver and plasma (Jiang et al., 2007; 2011). In conclusion, our results demonstrated that addition of oxidized fish oil increased MDA and decreased GSH-Px activity in the jejunal mucosa, changed the cytokines in jejunal extracts from a pro- to an antiinflammatory profile, and increased $\operatorname{sIgA}$ and de- creased NF- $\kappa \mathrm{B}$ concentrations. Collectively, these data show that dietary inclusion of moderate amounts $(20 \mathrm{mg} / \mathrm{kg})$ of ISF is an effective way of reducing oxidative stress in the small intestine of young piglets fed diets containing oxidized fish oil.

\section{Acknowledgements}

We thank Prof. W. Bruce CURRIE (Department of Animal Science, Cornell University, USA) for editing this manuscript.

\section{Compliance with ethics guidelines}

Lin HUANG, Xian-yong MA, Zong-yong JIANG, You-jun HU, Chun-tian ZHENG, Xue-fen YANG, Li WANG, and Kai-guo GAO declare that they have no conflict of interest.

This study was conducted according to the Chinese Guidelines for the Use of Experimental Animals and Animal Welfare (Science and Technology Ministry of China, 2006) and approved by Animal Experimental Committee of Institute of Animal Science, Guangdong Academy of Agricultural Sciences. All institutional and national guidelines for the care and use of laboratory animals were followed.

\section{References}

Andrew, J.S., Griffith, W.H., Mead, J.F., et al., 1960. Toxicity of air-oxidized soybean oil. J. Nutr., 70:199-210.

Aw, T.Y., 1999. Molecular and cellular responses to oxidative stress and changes in oxidation-reduction imbalance in the intestine. Am. J. Clin. Nutr., 70(4):557-565.

Ban, H., Shigemitsu, K., Yamatsuji, T., 2004. Arginine and Leucine regulate $\mathrm{p} 70 \mathrm{~S} 6$ kinase and 4E-BP1 in intestinal epithelial cells. Int. J. Mol. Med., 13(4):537-543. http://dx.doi.org/10.3892/ijmm.13.4.537

Banan, A., Fields, J.Z., Zhang, Y., et al., 2001. iNOS upregulation mediates oxidant-induced disruption of F-actin and barrier of intestinal monolayers. Am. J. Physiol. Gastrointest Liver Physiol., 280:G1234-G1246.

Blikslager, A.T., Moeser, A.J., Gookin, J.L., et al., 2007. Restoration of barrier function in injured intestinal mucosa. Physiol. Rev., 87(2):545-564. http://dx.doi.org/10.1152/physrev.00012.2006

Burrin, D.G., Stoll, B., Jiang, R., et al., 2000. Minimal enteral nutrient requirements for intestinal growth in neonatal piglets: how much is enough? Am. J. Clin. Nutr., 71: 1603-1610

Cera, K.R., Mahan, D.C., Cross, R.F., et al., 1988. Effect of age, weaning and postweaning diet on small intestinal growth and jejunal morphology in young swine. J. Anim. Sci., 66(2):574-584. http://dx.doi.org/10.2527/jas1988.662574x

Chamulitrat, W., Skrepnik, N.V., Spitzer. J.J., 1996. Endotoxininduced oxidative stress in the rat small intestine: role of nitric oxide. Shock, 5(3):217-222. http://dx.doi.org/10.1097/00024382-199603000-00009

Chang, R.H., Feng, M.H., Liu, W.H., et al., 1997. Nitric oxide 
increased interleukin-4 expression in $\mathrm{T}$ lymphocytes. Immunology, 90(3):364-369. http://dx.doi.org/10.1111/j.1365-2567.1997.00364.x

Daniel, T., Alexander, M., Hubbard, W.J., et al., 2006. Nitric oxide contributes to the development of a post-injury Th2 $\mathrm{T}$ cell phenotype and immune dysfunction. J. Cell. Physiol., 208(2):418-427. http://dx.doi.org/10.1002/jcp.20677

Deng, Q., Xu, J., Yu, B., et al., 2010. Effect of dietary tea polyphenols on growth performance and cell-mediated immune response of post-weaning piglets under oxidative stress. Arch. Anim. Nutr., 64(1):12-21. http://dx.doi.org/10.1080/17450390903169138

de Wilde, A., Lieberherr, M., Colin, C., et al., 2004. A low dose of daidzein acts as an ER $\beta$-selective agonist in trabecular osteoblasts of young female piglets. J. Cell. Physiol., 200(2):253-262. http://dx.doi.org/10.1002/jcp.20008

Dixit, A.K., Bhatnagar, D., Kumar, V., et al., 2012. Antioxidant potential and radioprotective effect of soy isoflavone against gamma irradiation induced oxidative stress. $J$. Funct. Foods, 4(1):197-206. http://dx.doi.org/10.1016/j.jff.2011.10.005

Fan, J., Meng, Q., Guo, G., et al., 2010. Effects of early enteral nutrition supplemented with arginine on intestinal mucosal immunity in severely burned mice. Clin. Nutr., 29(1):124-130. http://dx.doi.org/10.1016/j.clnu.2009.07.005

Foti, P., Erba, D., Riso, P., et al., 2005. Comparison between daidzein and genistein antioxidant activity in primary and cancer lymphocytes. Arch. Biochem. Biophys., 433(2): 421-427. http://dx.doi.org/10.1016/j.abb.2004.10.008

Frankel, W.L., Zhang, W., Afonso, J., et al., 1993. Glutamine enhancement of structure and function in transplanted small-intestine in the rat. J. Parenter. Enteral Nutr., 17(1): 47-55. http://dx.doi.org/10.1177/014860719301700147

Goerke, M., Eklund, M., Sauer, N., et al., 2012. Standardized ileal digestibilities of crude protein, amino acids, and contents of antinutritional factors, mycotoxins, and isoflavones of European soybean meal imports fed to piglets. J. Anim. Sci., 90(13):4883-4895. http://dx.doi.org/10.2527/jas.2011-5026

Gookin, J.L., Rhoads, J.M., Argenzio, R.A., 2002. Inducible nitric oxide synthase mediates early epithelial repair of porcine ileum. Am. J. Physiol.-Gastrointest. Liver Physiol., 283(1):G157-G168. http://dx.doi.org/10.1152/ajpgi.00005.2001

Halliwell, B., Chirico, S., 1993. Lipid peroxidation: its mechanism, measurement, and significance. Am. J. Clin. Nutr., 57(5):715S-724S.

Huang, L., Jiang, Z.Y., Lin, Y.C., et al., 2011. Effects of $\mathrm{L}$-arginine on intestinal development and endogenous arginine-synthesizing enzymes in neonatal pigs. Afr. J.
Biotechnol., 10(40):7915-7925.

http://dx.doi.org/10.5897/AJB11.1180

Jelínková, L., Tučková, L., Cinová, J., et al., 2004. Gliadin stimulates human monocytes to production of IL-8 and TNF- $\alpha$ through a mechanism involving NF- $\mathrm{BB}$. FEBS Lett., 571(1-3):81-85.

http://dx.doi.org/10.1016/j.febslet.2004.06.057

Jensen, A.R., Elnif, J., Burrin, D.G., et al., 2001. Development of intestinal immunoglobulin absorption and enzyme activities in neonatal pigs is diet dependent. J. Nutr., 131(12):3259-3265.

Jiang, Z.Y., Jiang, S.Q., Lin, Y.C., et al., 2007. Effects of soybean isoflavone on growth performance, meat quality, and antioxidation in male broilers. Poult. Sci., 86(7): 1356-1362. http://dx.doi.org/10.1093/ps/86.7.1356

Jiang, Z.Y., Zhou, G.L., Lin, Y.C., et al., 2011. Effects of soybean isoflavones on in vitro antioxidative capacity of satellite cells of porcine skeletal muscles. Agric. Sci. Chin., 10(1):120-125 (in Chinese). http://dx.doi.org/10.1016/S1671-2927(11)60314-3

John, S.A., Wendell, H.G., James, F.M., et al., 1959. Toxicity of air-oxidized soybean oil. J. Nutr., 70(2):199-210.

Kalinski, P., Moser, M., 2005. Consensual immunity: success driven development of T-helper-1 and T-helper-2 responses. Nat. Rev. Immunol., 5(3):251-260.

http://dx.doi.org/10.1038/nri1569

Kelley, D.S., 2001. Modulation of human immune and inflammatory responses by dietary fatty acids. Nutrition, 17(7-8): 669-673. http://dx.doi.org/10.1016/S0899-9007(01)00576-7

Kim, M.J., Ryu, G.R., Kang, J.H., et al., 2004. Inhibitory effects of epicatechin on interleukin-1 $\beta$-induced inducible nitric oxide synthase expression in RINm5F cells and rat pancreatic islets by down-regulation of NF- $\mathrm{\kappa B}$ activation. Biochem. Pharmacol., 68(9):1775-1785. http://dx.doi.org/10.1016/j.bcp.2004.06.031

Kudsk, K.A., 2001. Importance of enteral feeding in maintaining gut integrity. Tech. Gastrointest. Endosc., 3(1): $2-8$.

http://dx.doi.org/10.1053/tgie.2001.19906

Lackeyram, D., Mine, Y., Widowski, T., et al., 2012. The in vivo infusion of hydrogen peroxide induces oxidative stress and differentially affects the activities of small intestinal carbohydrate digestive enzymes in the neonatal pig. J. Anim. Sci., 90(Suppl. 4):418-420. http://dx.doi.org/10.2527/jas.54011

Lee, C.H., Yang, L., Xu, J.Z., et al., 2005. Relative antioxidant activity of soybean isoflavones and their glycosides. Food Chem., 90(4):735-741. http://dx.doi.org/10.1016/j.foodchem.2004.04.034

Leitch, G.J., He, Q., 1999. Reactive nitrogen and oxygen species ameliorate experimental cryptosporidiosis in the neonatal $\mathrm{BALB} / \mathrm{c}$ mouse model. Infect. Immun., 67: 5885-5891. 
Li, D.F., Nelssen, J.L., Reddy, P.G., et al., 1990. Transient hypersensitivity to soybean meal in early-weaned pig. $J$. Anim. Sci., 68(6):1790-1799. http://dx.doi.org/10.2527/1990.6861790x

Li, D.F., Nelssen, J.L., Reddy, P.G., et al., 1991. Measuring suitability of soybean products for early-weaned pigs with immunological criteria. J. Anim. Sci., 69(8):3299-3307. http://dx.doi.org/10.2527/1991.6983299x

Li, Y., Ahmed, F., Ali, S., et al., 2005. Inactivation of nuclear factor $\kappa \mathrm{B}$ by soy isoflavone genistein contributes to increased apoptosis induced by chemotherapeutic agents in human cancer cells. Cancer Res., 65(15):6934-6943. http://dx.doi.org/10.1158/0008-5472.CAN-04-4604

Liu, J.B., Chang, S.K.C., Wiesenborn, D., 2005. Antioxidant properties of soybean isoflavone extract and tofu in vitro and in vivo. J. Agric. Food. Chem., 53(6):2333-2340. http://dx.doi.org/10.1021/jf048552e

Liu, J.F., Lee, Y.W., 1998. Vitamin C supplementation restores the impaired Vitamin E status of guinea pigs fed oxidized frying oil. J. Nutr., 128(1):116-122.

Maeda, T., Miyazono, Y., Ito, K., et al., 2010. Oxidative stress and enhanced paracellular permeability in the small intestine of methotrexate-treated rats. Cancer Chemother. Pharmacol., 65(6):1117-1123. http://dx.doi.org/10.1007/s00280-009-1119-1

Mau, M., Kalbe, C., Viergutz, T., et al., 2008. Effects of dietary isoflavones on proliferation and DNA integrity of myoblasts derived from newborn piglets. Pediatr. Res., 63(1):39-45. http://dx.doi.org/10.1203/PDR.0b013e31815b8e60

Mercer, D.W., Smith, G.S., Cross, J.M., et al., 1996. Effects of lipopolysaccharide on intestinal injury: potential role of nitric oxide and lipid peroxidation. J. Surg. Res., 63(1): 185-192. http://dx.doi.org/10.1006/jsre.1996.0245

Moreto, M., Perez-Bosque, A., 2009. Dietary plasma proteins, the intestinal immune system, and the barrier functions of the intestinal mucosa. J. Anim. Sci., 87(14_Suppl.):E92-E100. http://dx.doi.org/10.2527/jas.2008-1381

Morimoto, M., Watanabe, T., Yamori, M., et al., 2009. Isoflavones regulate innate immunity and inhibit experimental colitis. J. Gastroenterol. Hepatol., 24(6):1123-1129. http://dx.doi.org/10.1111/j.1440-1746.2008.05714.x

Otani, K., Shimizu, S., Chijiiwa, K., et al., 2000. Administration of bacterial lipopolysaccharide to rats induces heme oxygenase-1 and formation of antioxidant bilirubin in the intestinal mucosa. Digest. Dis. Sci., 45(12):2313-2319. http://dx.doi.org/10.1023/A:1005626622203

Ozacmak, H.S., Ozacmak, V.H., Barut, F., et al., 2014. Pretreatment with mineralocorticoid receptor blocker reduces intestinal injury induced by ischemia and reperfusion: involvement of inhibition of inflammatory response, oxidative stress, nuclear factor $\kappa \mathrm{B}$, and inducible nitric oxide synthase. J. Surg. Res., 191(2):350-361.

Pampusch, M.S., Bennaars, A.M., Harsch, S., et al., 1998.
Inducible nitric oxide synthase expression in porcine immune cells. Vet. Immunol. Immunopathol., 61:279-289.

Parikh, N.A., Katsetos, C.D., Ashraf, Q.M., et al., 2003. Hypoxia-induced Caspase-3 activation and DNA fragmentation in cortical neurons of newborn piglets: role of nitric oxide. Neurochem. Res., 28(9):1351-1357. http://dx.doi.org/10.1023/A:1024992214886

Pruett, S.B., 2003. Stress and the immune system. Pathophysiology, 9(3):133-153.

Science and Technology Ministry of China, 2006. The guiding suggestion about treating experimental animals amicably. Document No. 398.

Shang, H., Tsai, H., Chiu, W., et al., 2004. Effects of Arginine supplementation on mucosal immunity in rats with septic peritonitis. Clin. Nutr., 23(4):561-569. http://dx.doi.org/10.1016/j.clnu.2003.10.005

Slater, T.F., 1984. Free radical mechanisms in tissue injury. Biochem. J., 222(1):1-15. http://dx.doi.org/10.1042/bj2220001

Taylor-Robinson, A.W., 1997. Inhibition of IL2 production by nitric oxide: a novel self regulatory mechanism for Th1 cell proliferation. Immunol. Cell Biol., 75(2):167-175. http://dx.doi.org/10.1038/icb.1997.23

Valachovicova, T., Slivova, V., Bergman, H., et al., 2005. Soy isoflavones suppress invasiveness of breast cells by the inhibition of NF- $\mathrm{B} / \mathrm{AP}-1-d e p e n d e n t$ and independent pathways. Int. J. Oncol., 25(5):1389-1395.

VázquezAñón, M., Jenkins, T., 2007. Effects of feeding oxidized fat with or without dietary antioxidants on nutrient digestibility, microbial nitrogen and fatty acid metabolism. J. Dairy Sci., 90(9):4361-4867. http://dx.doi.org/10.3168/jds.2006-858

Xi, P.B., Jiang, Z.Y., Zheng, C.T., et al., 2011. Regulation of protein metabolism by glutamine: implications for nutrition and health. Front. Biosci., 16(1):578-597. http://dx.doi.org/10.2741/3707

Yousef, M.I., Kamel, K.I., Esmail, A.M., et al., 2004. Antioxidant activities and lipid lowering effects of isoflavone in male rabbits. Food Chem. Toxicol., 42(9):1497-1503. http://dx.doi.org/10.1016/j.fet.2004.04.012

Ypsilantis, P., Tentes, L., Lambropoulou, M., et al., 2008. Prophylaxis with mesna prevents oxidative stress induced by ischemia reperfusion in the intestine via inhibition of nuclear factor- $\mathrm{kB}$ activation. J. Gastroenterol. Hepatol., 23(2):328-335. http://dx.doi.org/10.1111/j.1440-1746.2007.05154.x

Yuan, S.B., 2007. Impacts of Oxidative Stress on Piglets and the Anti-stress Effect and Mechanism of Selenium. $\mathrm{PhD}$ Thesis, Sichuan Agriculture University, China (in Chinese).

Zhan, X., Qie, Y., Wang, M., et al., 2011. Selenomethionine: an effective selenium source for sow to improve Se distribution, antioxidant status, and growth performance of pig offspring. Biol. Trace Elem. Res., 142(3):481-491. http://dx.doi.org/10.1007/s12011-010-8817-8 


\section{中文概要}

题 目: 大豆异黄酮对饲喂氧化鱼油新生仔猪肠道抗氧化 功能及细胞因子的影响

目 的: 研究大豆异黄酮对氧化鱼油造成仔猪氧化应激的 缓解作用, 并初步探讨其作用机制。

创新点: 首次在仔猪肠道氧化应激模型中证明大豆异黄酮 可缓解仔猪氧化应激, 且此作用与提高其免疫功 能相关。

方 法: 将 72 头平均体重约 $1.8 \mathrm{~kg}$ 的 4 日龄杜 $\times$ (长 $\times$ 大) 三元杂公猪随机分为 3 组, 每组重复 6 次, 每次 重复包括 4 头猪: 对照组 (饲喂 $50 \mathrm{~g} / \mathrm{kg}$ 新鲜鱼油), 处理组 1 (添加 $50 \mathrm{~g} / \mathrm{kg}$ 氧化鱼油) 和处理组 2 (添 加 $50 \mathrm{~g} / \mathrm{kg}$ 氧化鱼油 $+20 \mathrm{mg} / \mathrm{kg}$ 大豆异黄酮）; 基
础日粮根据 NRC（2012）《猪的营养需要量》配 制, 每 3 小时饲喂一次, 记录每天采食量; 实验 期 21 天结束后, 称重, 计算平均日采食量、平 均日增重及料重比。用苏木精一伊红染色法观察 小肠形态结构, 并计算线毛高度和隐窝深度, 应 用南京建成试剂盒测定肠道中抗氧化酶的活性, 应用酶联免疫吸附测定（ELISA）试剂盒测定细 胞炎症相关因子和细胞凋亡相关因子的表达。

结 论: 饲喂氧化鱼油引起新生仔猪肠道产生氧化应激, 引起仔猪生长性能下降、肠道发育受损、细胞凋 亡增加及免疫功能失调。而添加大豆异黄酮能减 缓氧化鱼油造成的肠道损伤, 提高肠道粘膜完整 性, 提高肠道粘膜细胞抗氧化功能和免疫功能。

关键词: 仔猪; 氧化鱼油; 生长性能; 大豆异黄酮; 抗氧 化功能 